\title{
Expansion and aerobiology of Ambrosia artemisiifolia L. in Slovakia
}

\author{
Michal Hrabovský', Jana Ščevková', Karol Mičieta', Janka Lafférsová , Jozef Dušička' \\ ${ }^{1}$ Department of Botany, Faculty of Natural Sciences, Comenius University, Bratislava, Slovakia \\ 2 Department of Environmental Biology, Public Health Office, Banská Bystrica, Slovakia
}

Hrabovský M, Ščevková J, Mičieta K, Lafférsová J, Dušička J. Expansion and aerobiology of Ambrosia artemisiifolia L. in Slovakia. Ann Agric Environ Med. 2016; 23(1): 64-70. doi: 10.5604/12321966.1196854

\begin{abstract}
Introduction and objective. The invasive alien species Ambrosia artemisiifolia cause environmental, agronomical and medical problems in many regions of the world, including Slovakia. The purpose of this study was to survey the spread and distribution of this species in Slovakia and to analyse its airborne pollen pattern.

Materials and methods. To evaluate the spatiotemporal dynamics of Ambrosia invasion in the territory of Slovakia, herbarium specimens, published databases and field investigations were considered. Aerobiological sampling was based on the analysis of pollen records at five aerobiological stations in Slovakia. For Bratislava and Banská Bystrica Monitoring stations, trends in Ambrosia pollen seasons were determined using Mann-Kendall test and Sen's slope estimator.

Results. Since the first record of $A$. artemisiifolia in Slovakia, the number of its colonies and its spread rate has increased considerably, and the colonisation of this species has been successful mainly in the south-western part of the country. Highest airborne pollen counts were recorded in Nitra, Trnava and Bratislava Monitoring Stations situated in the areas most infested by A. artemisiifolia in Slovakia. However, high pollen counts were also noted in Banská Bystrica and Košice Monitoring Stations situated in areas where the source species was less abundant. During the study period, the number of days on which the pollen concentration exceeded the threshold of sensitivity increased significantly (+1.33 days/year) in Banská Bystrica, whereas the peak value decreased significantly (-13.37 pollen/year) in Bratislava.

Conclusion. The number of the populations of $A$. artemisiifolia has increased considerably in recent years. Besides the most infested areas, high airborne pollen counts were also recorded in territories where the plant species was less abundant. During the study period, the intensity of Ambrosia pollen seasons decreased in Bratislava, probably due to changes in landuse practices, while the increasing trend in the pollen seasons intensity in Banská Bystrica mainly reflects the situation in the ragweed-infested remote areas due to long-range pollen transport.
\end{abstract}

\section{Key words}

plant invasions, Ambrosia artemisiifolia, airborne pollen, invasive weed, Slovakia

\section{INTRODUCTION}

Biological invasions represent a great danger for the conservation of biological diversity and ecosystem functions and constitute a health risk for human society [1]. Ambrosia artemisiifolia (common ragweed) of the Asteraceae family, originates from the temperate regions of North America, is considered as a bioinvader due to its enormous spread potential in Europe [2]. Ragweed spreads very easily and rapidly, mainly due to the large seed production; from about 3,000-62,000 seeds by each plant every year [3]. Moreover, ragweed seeds can rest in the soil for more than 30 years if the conditions are unsuitable for germination [4]. The long-range ragweed dispersal is mostly dependent on human activities, due to the lack of an effective, natural mechanism of its seed dispersion over long distances [5]. The most important introduction pathways related to anthropogenic activities include highways, railways, transport of soil, and agriculture machines [6]. However, taking into account the regional scale, the seeds can spread spontaneously by water, birds and wind $[7,8]$. The speed of its spontaneous spread is from 6-20 $\mathrm{km}$ per year [9].

The genus Ambrosia is represented by approximately 40 species worldwide [10]. Among them only A. artemisiifolia

Address for correspondence: Jana Ščevková, Department of Botany, Faculty of Natural Sceinces, Comenius University, 81102 Bratislava, Slovakia

E-mail: scevkova@fns.uniba.sk

Received: 16 March 2015; accepted: 30 June 2015
L. and A. trifida L. grow in Slovakia, whereas A. trifida occurs only randomly and to-date has not occurred expansively, in contrast to A. artemisiifolia which is commonly distributed, especially in the southern parts of the country [11]. This species requires a warm continental climate, dry soil and sufficient humidity during the summer time [12]. It generally occurs in dry fields and pastures, along roadsides and railway lines, and in waste grounds and fallow lands [12].

Ragweed is considered a noxious invasive species and as an important weed in agriculture, as well as a source of allergenic pollen [13]. Its pollen is one of the most important causes of allergic disease, such as seasonal rhinitis, conjunctivitis, asthma, and less commonly dermatitis in many areas in the United States [14] and Canada [15]. Its clinical relevance has dramatically increased even in Europe in the last decades [16]. In Europe, among the patients suffering of pollinosis, sensitization to ragweed pollen grains ranges from $2.5 \%$ in Finland to $60 \%$ in Hungary [16]. Ragweed pollen is recognised as highly allergenic also in Slovakia as a large part of pollen allergic individuals react to its pollen grains [17]. Furthermore, the existence of cross-reactivity between the pollen allergens of different species of Asteraceae family may enhance the risk of sensitization by $A$. artemisiifolia [18]. This anemophilous plant species produces millions of small pollen grains [19] and only a few pollen grains are enough to cause allergic symptoms in people [20]. The threshold value triggering clinical symptoms differ in different countries. In Austria, the threshold value is below 20 pollen grains $\mathrm{m}^{-3}$ 
$[21,22]$, whereas in France and Hungary the threshold value is below 13 and 30 pollen grains $\mathrm{m}^{-3}$, respectively [23, $24]$.

The introduction of $A$. artemisiifolia in Europe began in the second half of the $19^{\text {th }}$ century; however, its massive spread began at the beginning of the $20^{\text {th }}$ century after the First World War [25]. The species were transferred to Europe from America in shipments of agricultural products, e.g. purple clover seeds, potatoes or maize $[24,26]$. According to herbarium records, the first temporary colonization of this species in Europe was reported in 1863, simultaneously in Germany and France $[24,26]$.

In Europe, the most severely invaded regions by ragweed are: 1) Central Europe - Hungary, Austria and Slovakia, 2) Eastern Europe - Ukraine, European part of Russia, 3) South-Eastern Europe - Romania, Croatia and Serbia, and 4) Southern Europe - Slovenia, southern France and northern Italy $[21,24,27,29,30,31,32,33,34]$. Additionally, a few localities of ragweed have been also recorded in Czech Republic [28], Germany [35], Switzerland [36] and Poland [37].

\section{OBJECTIVE}

Very limited biological information on ragweed is available in Slovakia. Therefore, the aims of the study are: 1) to document the introduction, spread and distribution of this species, both in the past and present in Slovakia, and 2) to analyse its airborne pollen pattern based on the pollen records of five monitoring stations of the Pollen Information Service Network of Slovakia, situated in the western, central and eastern parts of the country. This is the first comprehensive study dealing with the introduction, spread and distribution of $A$. artemisiifolia in Slovakia.

\section{MATERIALS AND METHODS}

Slovakia is a landlocked Central European country with mountainous regions in the central and northern parts of the country, and lowlands in the south. It has a population of over five million and an area of about $49,000 \mathrm{~km}^{2}$, of which lowlands (95-299 m above sea level) represent 40\%, uplands and low hills (300-799 m above sea level) 45\%, and highlands (more than $800 \mathrm{~m}$ above sea level) 15\%. Slovakia belongs to the northern moderate climatic zone, with relatively warm summers and cold and humid winters. The weather differs from the mountainous north to the plains in the south. The warmest and driest region is southern Slovakia with an average annual temperature around $10.3^{\circ} \mathrm{C}$ and precipitation around $530 \mathrm{~mm}$. With increasing altitude, the temperature decreases and rainfalls increases.

The spatiotemporal dynamics of ragweed invasion is evaluated based on: 1) herbarium specimens deposited in the Herbarium of the Department of Botany, Comenius University (SLO), 2) published databases [11,38] and 3) field investigations carried out during 2004-2014. During the field investigations, potential habitats of $A$. artemisiifolia, mainly along roads and fields around villages situated in different parts of Slovakia, were inspected. Based on the obtained records, maps indicating the spatial distribution of A. artemisiifolia in Slovakia during four time periods (before 1969, 1989, 2009 and 2014) were compiled.

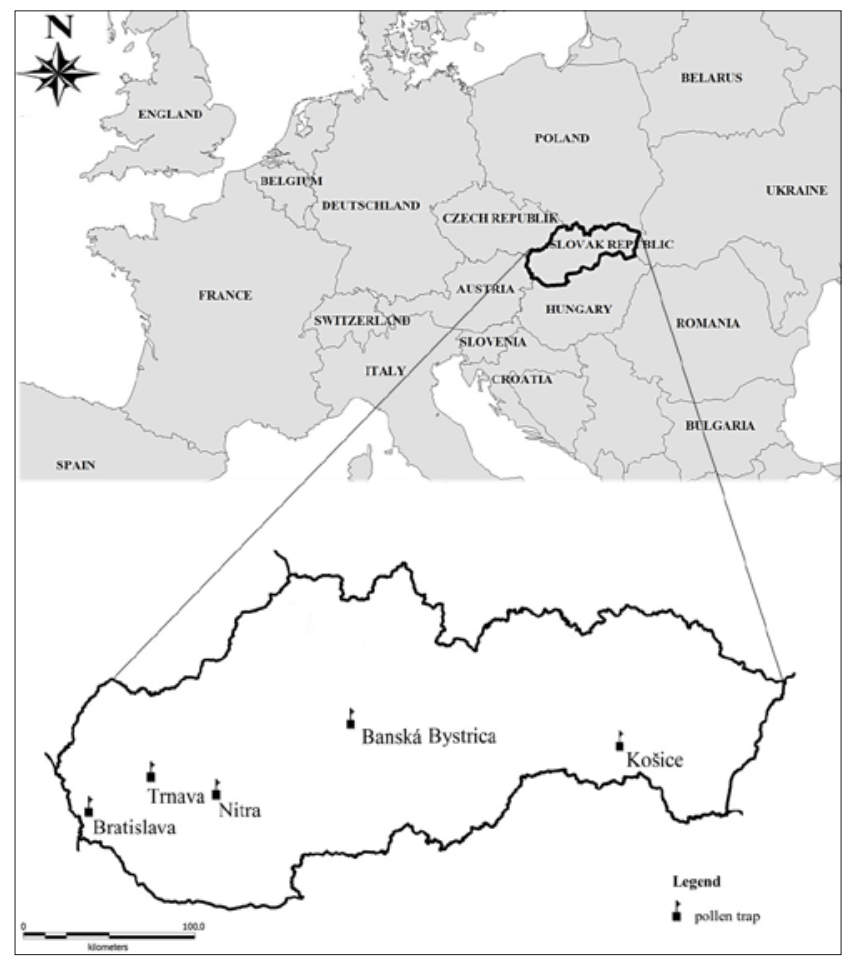

Figure 1. Locations of pollen monitoring stations in Slovakia

The filtration of the source data was based on the removal of duplicate data. Herbarium specimens having the same date (year) and same locality were treated as one specimen. All populations cited in the literature were checked and monitored in the field. Based on the botanical recording in the field, the localities situated less than two kilometres apart were merged into one locality and marked by a single dot on the distribution maps. Points on the maps do not correspond exactly to the number of ragweed localities recorded, whereas points lying close to each other are merged. Conversely, the extensive continuous populations along roads recorded as a single location, are depicted in the maps by two points.

In Slovakia, pollen monitoring started in 1995. Since that time, the Pollen Information Service Network of Slovakia has undergone many changes until the present state in which there are five monitoring stations in operation (Fig. 1). The aeropalynological study was carried out at five following monitoring sites: 1) Bratislava (16 years of study - 1995, 1997, 2001-2014), 2), Banská Bystrica (11 years of study - 2003, 2005-2014), 3) Košice, 4) Trnava (6-year period of study from 2009-2014), and (5) Nitra (5-year period of study from 20102014). Bratislava, Trnava and Nitra are situated in the western part of the country in the Podunajská nížina Lowland, Košice in the eastern part in the Východoslovenská nížina Lowland and Banská Bystrica in the uplands in Central Slovakia (Fig. 1). Table 1 shows the characteristics of these sites, their geographic location and topography.

Pollen sampling was performed using Burkard sevenday volumetric pollen traps [39] situated at the height of $10-18 \mathrm{~m}$ above the ground (Tab. 1). Ambrosia pollen data were collected and analysed in accordance with other researchers [40]. The average daily pollen concentrations are expressed as the number of pollen grains $\mathrm{m}^{-3}$.

Pollen seasons were calculated using the $90 \%$ method. The start of the season was defined as the date when $5 \%$ of the seasonal cumulative pollen count was trapped, and the end of 
Table 1. Geographical characteristic of the monitoring sites

\begin{tabular}{llcc}
\hline Site & $\begin{array}{c}\text { Geographical } \\
\text { location }\end{array}$ & $\begin{array}{c}\text { Height above sea } \\
\text { level }(\mathrm{m})\end{array}$ & $\begin{array}{c}\text { Height of pollen } \\
\text { trap above ground } \\
\text { level (m) }\end{array}$ \\
\hline Nitra & $48^{\circ} 18^{\prime} \mathrm{N}, 18^{\circ} 05^{\prime} \mathrm{E}$ & 167 & 14 \\
\hline Bratislava & $48^{\circ} 08^{\prime} \mathrm{N}, 17^{\circ} 06^{\prime} \mathrm{E}$ & 152 & 10 \\
\hline Trnava & $48^{\circ} 22^{\prime} \mathrm{N}, 17^{\circ} 35^{\prime} \mathrm{E}$ & 146 & 18 \\
\hline Košice & $48^{\circ} 43^{\prime} \mathrm{N}, 21^{\circ} 15^{\prime} \mathrm{E}$ & 208 & 15 \\
\hline Banská Bystrica & $48^{\circ} 44^{\prime} \mathrm{N}, 19^{\circ} 09^{\prime} \mathrm{E}$ & 368 & 12 \\
\hline
\end{tabular}

the season as the date when $95 \%$ of the seasonal cumulative pollen count was reached [41].

Annual trends of the following Ambrosia pollen season parameters were analysed:

1) seasonal pollen index (SPI) - sum of daily average pollen concentration recorded during the pollen season;

2) peak daily pollen concentration;

3) start; 4) end, and 5) duration of the pollen season.

To evaluate the statistical significance and the slope of existing trends, non-parametric Mann-Kendall test and Sen's method $[42,43]$ were used. The trend analysis was performed only on data collected from the stations in Bratislava and Banská Bystrica, since this type of analysis requires extensive data sets (more than 10 years). All data analyses were carried out by Statistica 10.

\section{RESULTS AND DISCUSSION}

The spread and distribution of Ambrosia artemisiifolia in Slovakia. The first records of A. artemisiifolia in the southwestern and south-eastern parts of Slovakia date back to 1949 and 1957, respectively [11]. Based on the long distance between the first localities (more than $300 \mathrm{~km}$ ) it was deduced that there were two ways that this species spread to Slovakia: from Pannonia and the East [11]. Mentioned author pointed out that the populations coming from Pannonia, eastern Hungary, colonized the territory of south-western Slovakia during the 1940s, while the south-eastern part of the country was colonized during the 1950s by ragweed seeds coming from Ukraine in connection with the transport of iron ore and eastern crops. The theory of spontaneous spread of ragweed from Hungary is improbable since the ragweed localities found in Hungary in a given time period were located more than $100 \mathrm{~km}$ away from the Slovak border. Contrary to this theory, it is assumed that the origin of

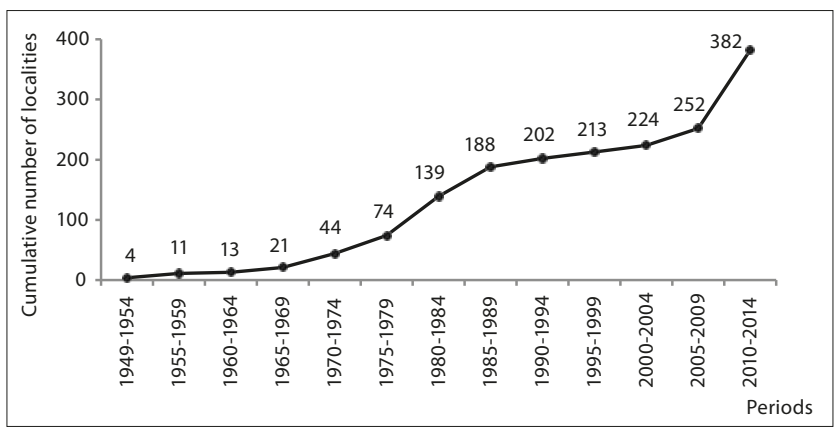

Figure 2. The curve of cumulative number of Ambrosia artemisiifolia localities in Slovakia, years 1949-2014 ragweed populations in south-west Slovakia is most likely derived from native Canadian populations. The reason is that in the years 1946-1947, Europe suffered a climate catastrophe. Cold and extreme drought devastated crop production [44]. In 1947-1948, based on the political and economic situation in Central Europe, the former Soviet Union purchased from Canada for former Czechoslovakia crops accidentally contaminated by ragweed [44]. This theory is also confirmed by a genetic study which revealed that contrary to ragweed populations in Western Europe originating in the United States, the populations in Central and Eastern Europe probably originated in Canada [45].

In Slovakia, the first references of the genus Ambrosia dates back to 1949 , when samples of $A$. artemisiifolia were found in Komárno and Vráble (SW Slovakia) [11]. Since that time, the number of its localities gradually increased; however, until 1969, it still remained as a very rare immigrant (Fig. 3a). According to herbarium records, in the period

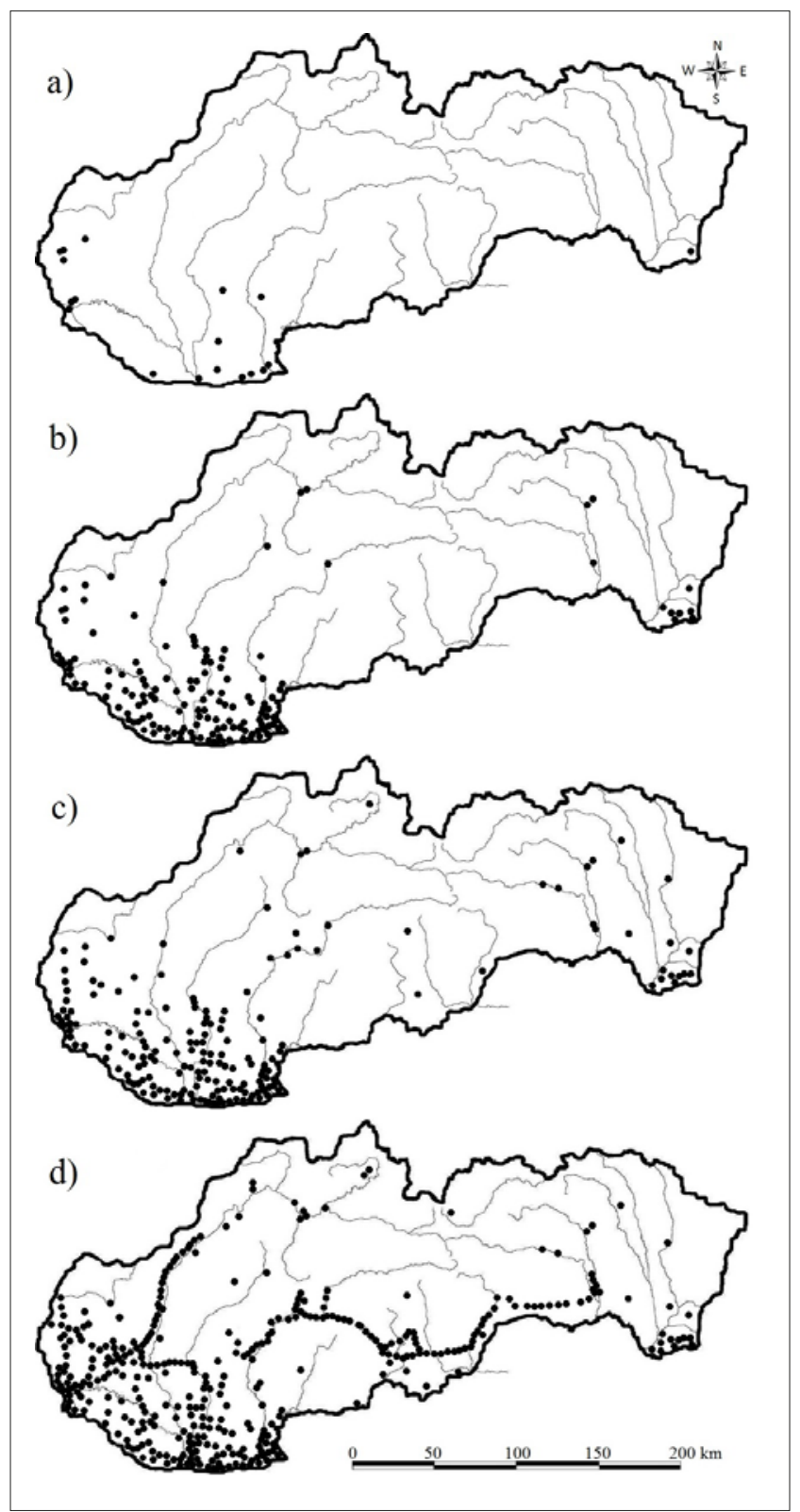

Figure 3. Distribution of Ambrosia artemisiifolia records in Slovakia in 1949-1969 (a), 1970-1989 (b), 1990-2009 (c) and 2010-2014 (d) 
between 1949-1969, this species was recorded 21 times (Fig. 2), mainly in port cities, at railway lines and in maize fields. The most intense ragweed immigration in Slovakia took place after 1970. In the period of 20 years (1970-1989) this species was recorded 167 times (Fig. 2). In this period, the species became invasive and gradually spread in the Danube lowland (Fig. 3b), where it occurred in fields, in rural and urban environments and along railway lines. Only 6 of the above mentioned 167 ragweed localities were located outside lowlands. During the next 20 -year period (1990-2009), the number of records decreased to 64 (Fig. 2), with 45 of them were located outside of lowlands. This period is characteristic by an increase in the number of ragweed populations along roads, and by the accidental introduction of them at higher altitudes (Fig. 3c). Starting in 2010, the number of ragweed records significantly increased with the main occurrence along highways and main roads (Fig. 3d). In the short period of five years (2010-2014), this species was recorded 130 times (Fig. 2). The reason of this much higher spreading rate of the species through the country in the last few years is the increase in the transportation of goods and increase in communication networks, especially highways in Slovakia. This is in accordance with other researchers $[6,24]$ who pointed out that human activities plays an important role in the spreading of ragweed species.

Altogether, 461 ragweed records of published databases, 122 records of field investigations and 41 herbarium specimens were analysed, of which 382 were used for the compilation of spatial distribution maps. Based on the field investigations, it was observed that the size of local populations at particular sites varied from a few to thousands of individuals. Ragweed forms continuous populations along roads over one kilometre in length, and also some localities previously published as being separate, which have recently formed connected areas.

There are two main invaded areas in Slovakia, situated in the south-west and south-east of the country (Fig. 3), However, the number of ragweed populations is incomparably lower in the south-eastern than in the south-western part of the country. The expansive behaviour of the western Slovak population of ragweed compared to the east could by caused by several factors. In the first years of introduction of the species, there were found several separated populations in the west, while in the east only one population occurred. Thus, genetic variability was higher in the west than in the east. The higher the genetic variability of introduced populations, the more successful is the introduction into new habitats and the higher evolutionary potential of the species $[46,47,48]$. One of the most important factors for invasion is intraspecific hybridization, which increases the adaptability of the species to new conditions [49]. In western Slovakia, populations were in closer contact with populations in western Hungary which, due to an earlier introduction, could have a different origin than Slovak populations which mutually increased their genetic variability. The Hungarian populations were also already in an advanced stage of adaptation. The population in the east were less adapted to the hilly vegetation ranges and more isolated from the Hungarian populations; therefore, their adaptation lasted longer. These populations have spread just south along the Tisza River and colonized eastern Hungary.

From the most infested area situated in the south-western part of Slovakia, ragweed is extending to east and northeast along the highways and main roads during the last few years (Fig. 3d). This is in accordance with other researchers who concluded that linear corridors, such as highways and railways, facilitate the invasion of alien species [50]. Some individual localities situated in central and northern Slovakia consist of populations of only a few individuals, which were randomly introduced in higher altitudes and have not spread to other areas.

In the prognosis of the spread of ragweed throughout the country it was predicted that only lowland (less than $300 \mathrm{~m}$ above sea level), or rarely hill-land areas (300-500 m above sea level) situated in southern and central parts of Slovakia will be invaded by this species [11]. However, since 1980, the species has occurred increasingly in up-hill territories (more than $500 \mathrm{~m}$ above sea level) situated in northern part of the country [38]. The spreading rate of ragweed populations seems to indicate that this species has found in Slovakia an ideal habitat for its expansion.

Dynamics of airborne pollen of Ambrosia artemisiifolia in Slovakia. The aeropalynological studies revealed that the airborne Ambrosia pollen concentrations in Slovakia varied according to season and monitoring station. The sums of the mean daily pollen concentrations during the pollen season (seasonal pollen index - SPI) measured at five monitoring stations in Slovakia in 1995-2014, are shown in Table 2. Taking into consideration all monitoring sites and years, both the highest and lowest SPI was recorded in Banská Bystrica: 3,898 pollen grains $\mathrm{m}^{-3}$ in 2009 and 251 pollen grains $\mathrm{m}^{-3}$ in the 2007 pollen season, respectively. Of all monitoring sites, the highest mean of the SPIs was recorded in Nitra (2,230 pollen grains) for the 5-year period 2010-2014, whereas the lowest was noted in Banská Bystrica $(1,427$ pollen grains) for the period of 11 years - 2003, 2005-2014.

Table 2. Seasonal pollen indexes of daily average pollen concentrations registered for Ambrosia airborne pollen in 5 monitoring sites in Slovakia

\begin{tabular}{|c|c|c|c|c|c|}
\hline Year/station & Bratislava & $\begin{array}{l}\text { Banská } \\
\text { Bystrica }\end{array}$ & Košice & Trnava & Nitra \\
\hline 1995 & 2,196 & * & * & * & * \\
\hline 1996 & * & * & * & * & * \\
\hline 1997 & 1,651 & * & * & * & * \\
\hline 1998 & * & * & * & * & * \\
\hline 1999 & * & * & * & * & * \\
\hline 2000 & * & * & * & * & * \\
\hline 2001 & 1,583 & * & * & * & * \\
\hline 2002 & 2,318 & * & * & * & * \\
\hline 2003 & 1,360 & 410 & * & * & * \\
\hline 2004 & 1,574 & * & * & * & * \\
\hline 2005 & 1,926 & 330 & * & * & * \\
\hline 2006 & 2,036 & 297 & * & * & * \\
\hline 2007 & 1,126 & 251 & * & * & * \\
\hline 2008 & 727 & 2,010 & * & * & * \\
\hline 2009 & 959 & 3,898 & 2,264 & 1,260 & $*$ \\
\hline 2010 & 659 & 1,097 & 899 & 834 & 964 \\
\hline 2011 & 1,885 & 3,734 & 2,755 & 2,629 & 1,733 \\
\hline 2012 & 1,594 & 1,783 & 547 & 2,052 & 3,660 \\
\hline 2013 & 1,855 & 564 & 501 & 873 & 2,023 \\
\hline 2014 & 1,505 & 1,317 & 2,311 & 2,831 & 2,771 \\
\hline
\end{tabular}

*not in operation 
It is important to note that the Nitra Monitoring Station is located in an area where Ambrosia is widespread while the Banská Bystrica Monitoring Station is located in an area where this species is less abundant (Fig. 3). This may suggest that the local populations have a substantial influence on the pollen records, particularly in the Nitra, Trnava and Bratislava Monitoring Stations situated in the Podunajská nížina Lowland, the most ragweed-infested area in Slovakia (Fig. 3). This is in accordance with other researchers [6] who have suggested that the amount of pollen recorded at a particular site can be generally considered as a reflection of the abundance of the species.

High SPIs were also recorded in the Banská Bystrica and Košice Monitoring stations situated in central and eastern Slovakia, respectively, despite the few ragweed localities located in these areas and its surroundings (Tab. 2; Fig. 3d). This may suggest that the long-range transport episodes, together with local populations, could also have a substantial influence on the pollen records in this area situated close to regions where ragweed is widely widespread, such as Podunajská nížina Lowland (SW Slovakia) and Hungary. Ambrosia pollen is able to be transported over long distances [51]; therefore, it cpuld be responsible for high airborne pollen concentrations in the territories where the source plant is scarce [52]. In this sense, it can be assumed that a certain part of ragweed pollen recorded in the Banská Bystrica Monitoring Station, could have originated from allochthonous sources. Similar findings were observed for Poland [53] and for Catalonia (NE Spain) [6], where Ambrosia has a limited distributions, but the pollen was frequently noted at monitoring stations.

Ambrosia pollen seasons have a tendency towards a decreasing intensity in Bratislava, whereas in Banská Bystrica a slight increase in SPI was observed during the study period. However, in both cases, these trends were not statistically significant (Tab. 4). In Poland [54] and Switzerland [55], the annual total Ambrosia pollen concentrations showed a strong and statistically significant decreasing tendency during the study period. In contrast, growing trends of Ambrosia pollen concentration were observed in Austria [21] and in the Czech Republic [28]. Of all the monitoring stations, the highest Ambrosia peak pollen value was recorded in Banská Bystrica $\left(\right.$ mean $=264$ pollen $\left.\mathrm{m}^{-3}\right)$, whereas the lowest was recorded in Bratislava $\left(\right.$ mean $=190$ pollen $\mathrm{m}^{-3}$ ). In Bratislava, Ambrosia peak pollen values have a significantly decreasing intensity $(-13.37$ pollen/year, $\mathrm{p}<0.05)$ during the study period (Tab. 4). It is assumed that the tendency towards a decreasing intensity of Ambrosia pollen seasons in Bratislava could be related to land-use practices and urbanisation, resulting in a reduction of abandoned areas where the weeds are usually abundant. For example, some researchers [56] reported that the significant decreases for weed pollen season intensity could possibly be explained by intensification of weed control.

At all the sites in all years of monitoring, the number of pollen grains on peak days exceeded the threshold value for sensitisation, which is considered to be below 20 pollen grains $\mathrm{m}^{-3}$ [21]. When considered all monitoring years as a group, the mean number of days when the mean daily pollen concentration exceeds threshold of sensitivity ranged between 12 days (Banská Bystrica) and 28 days (Nitra) (Tab. 3). According to reports from neighbouring countries, in Hungary and Poland there are 25-30 days and 1-2 days, respectively, in the critical period with daily
Table 3. Descriptive statistics of Ambrosia pollen seasons in Bratislava (16-year period: 1995, 1997, 2001-2014), Banská Bystrica (11-year period: 2003, 2005-2014), Košice and Trnava (6-year period: 2009-2014) and Nitra (5-year period: 2010-2014)

\begin{tabular}{|c|c|c|c|c|c|c|c|}
\hline \multirow{2}{*}{$\begin{array}{l}\text { Monitoring } \\
\text { station } \\
\text { Start date } \\
\text { (DOY) }\end{array}$} & & \multicolumn{6}{|c|}{ Characteristics of pollen season } \\
\hline & & $\begin{array}{l}\text { End } \\
\text { date } \\
\text { (DOY) }\end{array}$ & $\begin{array}{c}\text { Duration } \\
\text { (days) }\end{array}$ & $\begin{array}{c}\text { Peak value } \\
\text { (pollen } \\
\mathrm{m}^{-3} \text { ) }\end{array}$ & $\begin{array}{c}\text { SPI } \\
\text { (pollen) }\end{array}$ & $\begin{array}{l}\text { No. of days } \\
\text { Pollen: }>20\end{array}$ & \\
\hline \multirow{4}{*}{ Bratislava } & Mean & 225 & 262 & 37 & 190 & 1,560 & 21 \\
\hline & Max & 231 & 269 & 51 & 391 & 2,318 & 34 \\
\hline & Min & 219 & 252 & 27 & 37 & 659 & 8 \\
\hline & SD & 3.9 & 4.3 & 7.0 & 105.2 & 492.7 & 6.6 \\
\hline \multirow{4}{*}{$\begin{array}{l}\text { Banská } \\
\text { Bystrica }\end{array}$} & Mean & 224 & 260 & 37 & 264 & 1,427 & 12 \\
\hline & Max & 235 & 277 & 57 & 865 & 3,898 & 26 \\
\hline & Min & 205 & 243 & 19 & 29 & 251 & 3 \\
\hline & SD & 8.3 & 9.8 & 12.2 & 249.9 & $1,328.8$ & 8.0 \\
\hline \multirow{4}{*}{ Košice } & Mean & 223 & 261 & 39 & 230 & 1,546 & 17 \\
\hline & Max & 234 & 266 & 53 & 338 & 2,755 & 30 \\
\hline & Min & 211 & 253 & 31 & 91 & 501 & 6 \\
\hline & SD & 9.0 & 4.5 & 10.4 & 85.9 & $1,007.1$ & 10.3 \\
\hline \multirow{4}{*}{ Trnava } & Mean & 225 & 260 & 36 & 244 & 1,747 & 17 \\
\hline & Max & 232 & 274 & 43 & 404 & 2,831 & 24 \\
\hline & Min & 219 & 253 & 26 & 102 & 834 & 12 \\
\hline & SD & 5.3 & 7.5 & 6.3 & 117.7 & 881.0 & 5.0 \\
\hline \multirow{4}{*}{ Nitra } & Mean & 219 & 264 & 46 & 207 & 2,230 & 28 \\
\hline & Max & 226 & 278 & 72 & 291 & 3,660 & 42 \\
\hline & Min & 207 & 253 & 28 & 96 & 964 & 9 \\
\hline & SD & 7.9 & 9.7 & 16.3 & 75.9 & $1,028.4$ & 12.8 \\
\hline
\end{tabular}

DOY - day of the year from 1 January; SPI - total amount of pollen during pollen season.

Table 4. Mann-Kendall trend test (test tau column) and Sen's slope estimate ( $Q$ column) of pollen season parameters of Ambrosia in Bratislava and Banská Bystrica

\begin{tabular}{lcccc}
\hline \multirow{2}{*}{ Spore season parameter } & \multicolumn{2}{c}{ Bratislava } & \multicolumn{2}{c}{ Banská Bystrica } \\
\cline { 2 - 5 } & tau & $Q$ & tau & $Q$ \\
\hline Start date (DOY) & -0.31 & -0.42 & 0.06 & 0.33 \\
\hline End date (DOY) & 0.16 & 0.11 & 0.11 & 0.50 \\
\hline Duration (days) & 0.25 & 0.53 & 0.09 & 1.00 \\
\hline Peak value (pollen $\mathrm{m}^{-3}$ ) & $-0.45^{*}$ & -13.37 & 0.16 & 13.00 \\
\hline SPI (pollen) & -0.28 & -34.71 & 0.24 & 98.14 \\
\hline Number of days (pollen $>20)$ & 0.16 & 0.33 & $0.56^{*}$ & 1.33 \\
\hline
\end{tabular}

${ }^{*} p<0.05$

pollen concentrations over the allergological threshold value [57-58]. For the Nitra, Bratislava and Trnava Monitoring stations, more often than for the Banská Bystrica and Košice Monitoring stations, airborne Ambrosia pollen concentration exceeded the threshold of sensitivity (Tab. 3). The number of days with average daily pollen concentration higher than 20 pollen grains $\mathrm{m}^{-3}$ have a tendency towards increasing intensity in both analysed monitoring stations during the study period, but the only significant trend was for Banská Bystrica $(+1.33$ days/year, $\mathrm{p}<0.05)$ (Tab. 4). It is expected that this increasing trend in Banská Bystrica is primarily associated with the long-range pollen transport from the heavily-infested areas, as the source plant is not abundant in this area and its nearest surroundings. In contrast to the 
presented results, a trend towards smaller number of days on which the Ambrosia pollen concentration exceeded 13 and 30 pollen grains $\mathrm{m}^{-3}$ was observed in Szczecin, north-west Poland [54].

Ragweed pollen is present in the air of Slovakia between the beginning of July until the end of October, with the maximum pollination between mid-August and midSeptember. In the remaining months, only sporadic pollen grains were detected in the air. Of all monitoring sites, the Ambrosia pollen season started earliest in Nitra (mean = 219 DOY, on 7 August) (Tab. 3). Within the remaining four stations, the mean values of pollen season start dates were very similar, ranging from 223-225 DOY (11-13 August) (Tab. 3). In Bratislava, the Ambrosia pollen seasons started earlier during the studied period; however, this trend was not statistically significant (Tab. 4). Similarly to the current results, the earlier start dates of pollen seasons of weed plants were recorded in Central Europe during the last decades [59]. The mean values of pollen season end dates were very similar within the investigated monitoring stations, and occurred from 260-264 DOY (17-21 September) (Tab. 3). No significant trend in pollen season end dates was found during the analysed years (Tab. 4).

Taking all monitoring stations into account, the longest pollen season was observed for Nitra (mean $=46$ days) (Tab. 3). In the 16 years of the study, the trend towards a lengthening of pollen seasons was seen for Bratislava, but this trend was not statistically significant (Tab. 4). Contrary to these results, the strong trend towards a shortening of the Ambrosia pollen season was noted in Szczecin, Poland, over a period of 13 years (2000-2012) [54].

\section{CONCLUSIONS}

The purpose of collecting data and mapping the current and past distribution of A. artemisiifolia in Slovakia was primarily to show the extent to which the species has invaded the country. The spread of the species across Slovakia from the time of its first mention in natural habitats to the present situation (1949-2014), regarding 5-year periods shows an accelerated increasing expansion throughout the country. The colonisation of this species was successful mainly in the south-western part of the country. The increase in the number of ragweed populations has been also recorded in hilly areas during the last decades; however, only with an islet character. Recently, two clear fronts of spread along the highways and main roads (from west to east and north-east) have been recognizable in Slovakia, with the initial spread mediated by shipping. The further spread in local regions was caused by agricultural activities and rail transport. The newest phenomenon is the spreading along roads, where populations form almost continuous stands in lowland and hill-land ranges. It is assume that the expansion has not yet reached its culmination peak, and due to climatic fluctuations, a temporary occurrence is expected even in such habitats where the species have not been expected in the past. Understanding the spatial distribution of the species is a key step in predicting its future spread in the region, and developing control measures to help prevent this spread.

In order to contribute to a better knowledge of the tendencies of the species throughout the country, the airborne pollen pattern was also analysed. The highest means of the SPIs were recorded in the Nitra, Trnava and Bratislava Monitoring stations located in the most infested areas by A. artemisiifolia in Slovakia. It is therefore suggested that the local populations of this species have a major influence on the airborne pollen quantity in Slovakia. However, there could also be a certain influence of the allochthonous populations on the pollen concentrations, especially in the Banská Bystrica and Košice areas, where the source plant is less abundant, whereas the amount of captured airborne pollen seems to be high.

Ambrosia pollen seasons in Bratislava and Banská Bystrica changed over the period of 16 and 11 years, respectively. In Bratislava, pollination periods of Ambrosia now start earlier and last longer. However, these trends are not significant. The intensity of pollen seasons were found to be decreasing in Bratislava probably due to intense urbanisation in recent years. The peak pollen values decreased significantly ( -13.37 pollen/ year), while the decreasing trend in SPI was not significant. In contrast, the pollen seasons have a tendency (not significant) towards increasing intensity in Banská Bystrica, a town with less intensive urbanisation. The number of days on which the pollen concentration exceeded the threshold of sensitivity showed an increasing tendency during the study period in both analysed stations, but the only significant trend was for Banská Bystrica (+1.33 days/year). This significant trend is most likely related to long-range pollen transport from the regions where, unlike the Banská Bystrica area, the source plant species is abundant.

\section{Acknowledgements}

This study is the result of a project of the Comenius University in Bratislava Science Park, supported by the Research and Development Operational Programme funded by the ERDF, Grant No. ITMS 26240220086. The study was also supported by Grant Agency VEGA (Bratislava), Grant No. 1/0380/13.

\section{REFERENCES}

1. Vitousek PM, D’Antonio C, Loope LL, Rejmánek M, Westbrooks R. Introduced species: a significant component of human-caused global change. New Zeland J Ecol. 1997; 21: 1-16.

2. Lambdon PW, Pyšek P, Basnou C, Hejda M, Arianoutson M, Essel F, et al. Alien flora of Europe: species diversity, temporal trends, geographical patterns and research needs. Preslia. 2008; 80: 101-149.

3. Dickerson JCT, Sweet RD. Common ragweed ecotypes. Weed Sci. 1971; 19: 64-69.

4. Gadermaier G, Dedic A, Obermeyer G, Frank S, Himly M, Ferreirova F. Biology of weed pollen allergens. Curr. Allergy Asthma Rep. 2004; 4: 391-400.

5. Basset IJ, Crompton CW. The biology of Canadian weeds, Ambrosia artemisiifolia L. and A. psilostachya DC. J Plant Sci. 1975; 55: 463-476.

6. Fernández-Llamazares Á, Belmonte J, Alarcón M, López-Pacheco M. Ambrosia L. in catalonia (NE Spain): expansion and aerobiology of a new bioinvader. Aerobiologia. 2012; 28: 435-451.

7. Brandes D, Nitzsche J. Verbreitung, Ökologie und Soziologie von Ambrosia artemisiifolia L. in Mitteleuropa. Tuexenia. 2007; 27: 167-194.

8. Jäger S, Litschauer R. Ragweed (Ambrosia) in Austria. In: Spieksma FTH (Ed.). Ragweed in Europe. The $6^{\text {th }}$ International Congress on aerobiology, Satellite Symp. Proc. Perugia, Italy 1998, 6-8.

9. Cvitanović S, Znaor L, Kanceljak-Macan B, Macan J, Gudelj I, Grbić D. Allergic rhinitis and asthma in Southern Croatia: impact of sensitization to Ambrosia elatior. Croat Med J. 2007; 48:68-75.

10. Allard HA. The North American ragweed and their occurrence in other parts of the world. Science. 1943; 98: 292-294.

11. Jehlík V, Hejný S, Kropáč Z, Lhotská M, Kopecký K, Slavík B et al. Cizí expanzivní plevele České republiky a Slovenské republiky./The foreign expansive weeds of the Czech Republic and the Slovak Republic/. Academia, Praha. 1998; 165-179. 
12. Fumanal B, Girod C, Fried G, Bretagnolle F, Chauvel B. Can the large ecological amplitude of Ambrosia artemisiifolia explain its invasive success in France? Weed Research. 2008; 48: 349-359.

13. Smith M, Cecchi L, Skjøth CA, Karrer G, Šikoparija B. Common ragweed: A threat to environmental health in Europe. Invironment International. 2013; 61: 115-126.

14. White JF, Bernstein DI. Key pollen allergens in North America. Ann Allergy Asthma Immiunol. 2003; 91: 425-435.

15. Chan-Yeung M, Anthonisen NR, Becklake MR, Browie D, Sonia Buist A, Dimich-Ward H et al. Geographical variations in the prevalence of atopic sensitization in six study sites across Canada. Allergy. 2010; 65: 1404-1413.

16. Burbach GJ, Heinzerling LM, Rohnelt C, Bergmann KC, Behrendt H, Zuberbier T. Ragweed sensitization in Europe - GA(2)LEN study suggests increasing prevalence. Allergy. 2009; 64: 664-665.

17. Hrubiško M. Polinóza - aktuálny problem aj v XXI. Storočí. Čast' III: poradie a skrížené reactivity alergénnych druhov stromov, tráv a bylín podla ich klinického významu. /Pollinosis - actual problem also in XXI. Century. Part III: sequence and cross reactivity of the tree, grass and plant allergen species by their clinical significance/. Klinická Imunológia a Alergológia. 1998; 2: 9-17.

18. D’Amato G, Cecchi L, Bonini S, Nunes C, Annesi-Maesano I, Behrendt $\mathrm{H}$ et al. Allergenic pollen and pollen allergy in Europe. Allergy. 2007; 62: 976-990.

19. Šaulienè I, Veriankaitè L, Šaulys A. Biometrical assessment of ragweed (Ambrosia artemisiifolia L.). Zemdirbystè. 2012; 99: 319-326.

20. Heinzerling L, Frew AJ, Bindslev-Jensen C, Bonini S, Bousquet J, Bresciani M. Standard skin prick testing and sensitization to inhalant allergens across Europe - a survey from the GA ${ }^{2}$ LEN network. Allergy. 2005; 60: 1287-1300.

21. Jäger S. Ragweed (Ambrosia) sensitisation rates correlate with the amount of inhaled airborne pollen. A 14-year study in Vienna, Austria. Aerobiologia. 2000; 16: 149-153

22. Bergmann KC, Werchan D, Zuberbier MM. The threshold value of Ambrosia pollen inducing acute nasal reactions is very low. Allergo J. 2008; 17: 375-376.

23. Laaidi K, Laaidi M. Airborne pollen of Ambrosia in Burgundy (France) 1996-1997. Aerobiologia. 1999; 15: 65-69.

24. Makra L, Juhász M, Béczi R, Borsos E. The history and impacts of airborne Ambrosia (Asteraceae) pollen in Hungary. Grana. 2005; 44: 57-64.

25. Csontos P, Vitalos M, Barina Z, Kiss L. Early distribution and spread of Ambrosia artemisiifolia in Central and Eastern Europe. Bot Helv. 2010; 120: 75-78.

26. Chauvel B, Dessaint F, Cardinal-Legrand C, Bretagnolle F. The historical spread of Ambrosia artemisiifolia L. in France from herbarium records. J Biogeogr. 2006; 33: 665-673.

27. Chrenová J, Mičieta K, Ščevková J. Monitoring of Ambrosia pollen concentration in the atmosphere of Bratislava (Slovakia) during years 2002-2007. Aerobiologia. 2010; 26: 83-88.

28. Rybníček O, Novotná B, Rybníčková E, Rybníček K. Ragweed in Czech Republic. Aerobiologia. 2000; 16: 287-290.

29. Rodinkova V. Palamarchuk O, Kremenska L. The most abundant Ambrosia pollen count is associated with the southern, eastern and the northern-eastern Ukraine. Alergologia et Immunologia. 2012; 9: 181.

30. Thibaudon M, Šikoparija B, Oliver G, Smith M, Skjøth CA. Ragweed pollen source inventory for France - The second largest centre of Ambrosia in Europe. Atmospheric Environment. 2014; 83: 62-71.

31. Bonini M, Albertini R, Brighetti MA, Ugolotti M, Travaglini A, (RIMAItalian Monitoring Network in Aerobiology). Ragweed pollen spread in in Italy. Second International Ragweed Conference, Lyon (France), March 28-29. 2012.

32. Šikoparija B, Radišic P, Pejak T, Šimic S. Airborne grass and ragweed pollen in the southern Panonnian Valley - consideration of rural and urban environment. Ann Agric Environ Med. 2006; 13: 263-266.

33. Peternel R, Čulig J, Srnec L, Mitic B, Vukusic I, Hrga I. Variation in ragweed (Ambrosia artemisiifolia L.) pollen concentration in Central Croatia, 2002-2004. Ann Agric Environ Med. 2005; 12: 11-16.

34. Juhász M, Juhász I, Gallovich R, Radisic P, Ianovici N, Peternel R et al. Last years ragweed pollen concentrations in the Southern part of Carpathian Basin, Proceedings. 11th symposium on analytical and environmental problems, Szeged, Hungary. 2004.
35. Brandes D, Nietzsche J. Biology, introduction, dispersal, and distribution of common ragweed (Ambrosia artemisiifolia L.) with special regard to Germany. Nachrichtenbl Deut Pflanzenschutzd. 2006; 58: 286-291.

36. Taramarcaz P, Lambelet C, Clot B, Keimer C, Hauser C. Ragweed (Ambrosia) progression and its health risks. Will Switzerland resist this invasion? Swiss Med Wkly. 2005; 135: 538-548.

37. Stepalska D, Myszkowska D, Wolek J, Piotrowicz K, Obtulowicz K. The influence of meteorological factors on Ambrosia pollen loads in Cracow, Poland, 1995-2006. Grana. 2008; 47: 297-304.

38. Hrabovský M, Mičieta K. The occurrence of an invasive species Ambrosia artemisiifolia in Slovakia in the years 2008-2014. Acta Botanica. 2014; 49: 9-12.

39. Hirst JM. An automatic volumetric spore trap. Ann Appl Biology. 1952; 39: 257-265.

40. Ščevková J, Dušička J, Chrenová J, Mičieta K. Annual pollen spectrum variations in the air of Bratislava (Slovakia): years 2002-2009. Aerobiologia. 2010; 26: 277-287.

41. Nilsson S, Persson S. Tree pollen spectra in the Stockholm region (Sweden), 1973-1980. Grana. 1981; 20: 179-182.

42. Mann HB. Nonparametric tests against trend. Econometrica. 1945; 13: 245-259.

43. Kendal MG. Rank correlation methods. Charles Griffin, London. 1975.

44. Wheatcroft SG. The Soviet famine of 1946-1947, the weather and human agency in historical perspective. Europe-Asia Studies. 2012; 64: 987-1005

45. Gladieux P, Giraud T, Jiss L, Genton BJ, Jonot O, Shykoff JA. Distinct invasion sources of common ragweed (Ambrosia artemisiifolia) in Eastern and Western Europe. Biol Invasions. 2011; 13: 933-944.

46. Marrs RA, Sforza R, Hufbauer RA. When invasion increases population genetic structure: a study with Centaurea diffusa. Biol Invasions. 2008; 10: $561-572$.

47. Wilson JR, Dormontt EE, Prentis PJ, Lowe AJ, Richardson DM. Something in the way you move: dispersal pathways affect invasion success. Trends in Ecology \& Evolution. 2009; 24: 136-144.

48. Barnaud A, Kalwij J, Berthouly S, Alazar C, McGeoch M, Jansen van Vuuren B. Are road verges corridors for weed invasion? Insights from the fine-scale spatial genetic structure of Raphanus raphanistrum. Weed Research. 2013; 53: 362-369.

49. Ellstrand NC, Schierenbeck K. Hybridization as a stimulus for the evolution of invasiveness in plants? PNAS. 2000; 97: 7043-7050.

50. Christen D, Matlack G. The role of roadsides in plant invasions: a demographic approach. Cons Biol. 2006; 20: 385-391.

51. Cecchi L, Torrigiani T, Albertini R, Zanca M, Ridolo E, Usberti I. The contribution of long-distance transport to the presence of Ambrosia pollen in central northern Italy. Aerobiologia. 2007; 23: 145-151.

52. Šikoparija B, Smith M, Skjøth CA, Radišić P, Milkovska S, Šimić S et al. The Pannonian plain as a source of Ambrosia pollen in Balkans. Int J Biometeorol. 2009; 53: 263-272.

53. Stach A, Smith M, Skjøth CA, Brandt J. Examining Ambrosia pollen episodes at Poznan (Poland) using back-trajectory analysis. Int J Biometeorol. 2007; 51: 1465-1484.

54. Puc M, Wolski T. Forecasting of the seleced features of Poaceae (R. Br.) Barnh., Artemisia L. and Ambrosia L. pollen season in Szczecin, north-western Poland, using Gumbel's distribution. Ann Agric Environ Med. 2013; 20: 36-47.

55. Clot B. Trends in airborne pollen: A overview of 21 years of data in Neuchâtel (Switzerland). Aerobiologia. 2003; 19: 227-234.

56. Ziello C, Sparks TH, Estrella N, Belmonte J, Bergmann KC, Bucher E, Brighetti MA, Damialis A, Detandt M, Galan C, Gehrig R, Grewling Ł, Gutierrez AM, Hallsdottir M, Kockhans-Bieda M-C, De Linares C, Myszkowska D, Paldy A, Sanchez A, Smith M, Thibaudon M, Travaglini A, Uruska A, Valencia Barrera RM, Vokou D, Wachter R, De Weger LA, Menzel A. Changes to airborne pollen counts across Europe. Plos One. 2012; 7: e3407.

57. Járai-Komlódi M. Ragweed in Hungary. $6^{\text {th }}$ Int Cong on Aerobiology, Satellite Symposium Procedings. Ragweed in Europe. ALK Abelló 1998.

58. Stępalska D, Szczepanek K, Myszkowska D. Variation in Ambrosia pollen concentration in Southern and Central Poland in 1982-1999. Aerobiologia. 2002; 18: 13-22.

59. Makra L, Matyasovszky I, Deák AJ. Trends in the characteristics of allergenic pollen circulation in central Europe based on the example of Szeged, Hungary. Atmos Environ. 2011; 45: 6010-6018. 